\title{
Effects of the methanolic extracts of Zizyphus spina christi, Olea europaea and Morus alba leaves in Streptozotocin- induced diabetic rats.
}

\author{
A. I. Othman", M. A. Amer", M. Abdel-Mogib **, R. F. Samaha* \\ *Zoology Department, ** Chemistry Department, Faculty of Science, Mansoura \\ University, Mansoura, Egypt
}

\begin{abstract}
Background:The present study aims to investigate the hypoglycemic, hypolipidimic and antioxidant effect of the methanolic crude extracts of Zizyphus spina christi, Morus alba and Olea europaea leaves, individually or in combination against diabetes induced rats by Streptozotocin (STZ).

Results:Hyperglycemia and hyperlipidaemia except in high density lipoproteins (HDL) were observed in serum after 5 weeks of STZ administration. This was associated with a depression in hepatic glutathione (GSH) concentration as well as hepatic catalase (CAT), glutathione-stransferase (GST) and superoxide dismutase (SOD) activates. In addition hepatic thiobarbituric acid-reactive substance (TBARS) and protein carbonyl (PC) were significantly elevated, indicating increased lipid and protein oxidation and oxidative stress. Depression in blood hemoglobin $(\mathrm{Hb})$ content, serum insulin levels, total antioxidant capacity (TAOC) and nitric oxide (NO) levels as well as body weight gain were also observed in diabetic rats. Administration of $100 \mathrm{mg} / \mathrm{kg}$ alcoholic extracts of Zizyphus spina christi, Morus alba and Olea europaea leaves 3 days before and after STZ injection daily for 5 weeks significantly ameliorated the oxidative stress evidenced by lowering TBARS \& PC as well as increasing hepatic GSH concentration and CAT, GST and SOD activates as compared with STZ treated rats. These effects were paralleled with marked protection against STZ induced hyperglycemia and disturbance of lipid profile. They also caused a great improvement in insulin levels, TAOC, $\mathrm{NO}, \mathrm{Hb}$ content and body weight gain. Conclussion:Thus, these results showed that the administration of the crude extracts of either Zizyphus spina christi, Morus alba or Olea europaea leaves individually or in combination might improve the clinical manifestation of diabetes and decrease the oxidative stress, this study supports the beneficial effects of these extracts especially Zizyphus spina christi, which showed marked amelioration and this may be attributed to the presence of saponin glycosides which have an inhibitory effect of serum glucose level in addition to enhance the cellular antioxidant defense. This activity contributes to the protection against oxidative damage in STZ induced diabetes.
\end{abstract}

Key words: diabetes; Zizyphus spina-christi; Olea europaea; Morus alba, antioxidants; lipids; oxidative stress markers; nitric oxide.

\section{Introduction:}

Diabetes mellitus is a chronic metabolic disease characterized by elevated blood glucose levels and disturbances in carbohydrate, fat, and protein metabolism. These metabolic abnormalities result, in part, from a deficiency of the blood sugar lowering hormone insulin; this deficiency in insulin results in type1 diabetes (IDDM).
Type2 diabetes mellitus or non-insulindependent diabetes mellitus (NIDDM) results from hyperglycemia caused by overproduction of glucose at the hepatic level or because of abnormal $\beta$ cell function or insulin resistance at target cells (Fajans et al., 1997). 
The field of herbal medicines research has been gaining significant importance in the last few decades and the demand to use natural products in the treatment of diabetes is increasing worldwide. The available literatures show that there are more than 400 plant species showing antidiabetic activity (Rai, 1995).

$\begin{array}{rcr}\text { Since } & \text { numerous } & \text { studies } \\ \text { demonstrated that oxidative } & \text { stress, }\end{array}$ mediated mainly by hyperglycemia-induced generation of free radicals, contributes to the development and progression of diabetes and related contributions, it became clear that ameliorating oxidative stress through treatment with antioxidants might be an effective strategy for reducing diabetic complications. To this end, several clinical trials investigated the effect of antioxidants on the prevention of diabetic complications (Ceriello and Motz, 2004)

Since Zizyphus spina christi, Olea europaea and Morus alba are wild trees commonly available in Egypt and their leaves are used in folk medicine for the treatment of diabetes mellitus, therefore deemed interesting to reexamine the potential antidiabetic activity of these leaves to determine their biological activity against the deleterious effects of diabetes mellitus.

\section{Material and Methods:}

Adult male albino rats weighing 160-180 g were used. They were kept under good ventilation; adequate stable diet and water.

Animals groups and experiments:

Rats were divided into the following groups each group contains 8 rats.

\section{Normoglycemic groups}

Normal control rats only received a single dose of citrate buffer, normal control rats received Zizyphus spina-christi methanolic extract at dose $100 \mathrm{mg} / \mathrm{kg}$, normal control rats received Olea europaea methanolic extract at dose $100 \mathrm{mg} / \mathrm{kg}$, normal control rats received Morus alba methanolic extract at dose $100 \mathrm{mg} / \mathrm{kg}$, normal control rats received a mixture of the previous extracts at dose $100 \mathrm{mg} / \mathrm{kg}$.

\section{Hyperglycemic groups}

Diabetic control rats received single dose of $\mathrm{STZ}$ at dose $50 \mathrm{mg} / \mathrm{kg}$ dissolved in citrate buffer ( $\mathrm{PH} 4.5$ ) diabetic group with single dose of STZ at dose $50 \mathrm{mg} / \mathrm{kg}$ received Zizyphus methanolic extract at dose $100 \mathrm{mg} / \mathrm{kg}$, diabetic group with single dose of STZ at dose $50 \mathrm{mg} / \mathrm{kg}$ received Olea europaea methanolic extract at dose $100 \mathrm{mg} / \mathrm{kg}$, diabetic group with single dose of STZ at dose $50 \mathrm{mg} / \mathrm{kg}$ received Morus alba methanolic extract at dose $100 \mathrm{mg} / \mathrm{kg}$, diabetic group with single dose of STZ at dose $50 \mathrm{mg} / \mathrm{kg}$ received a mixture of the previous extracts at dose $100 \mathrm{mg} / \mathrm{kg}$.

\section{Plant materials and preparation of the methanolic extracts:}

Leaves of Zizyphus spina christi and Morus alba were collected from trees growing at Mansoura University, Egypt, leaves of Olea europaea were purchased from local markets. Fresh leaves (1 kg from each plant) were washed, air dried, powdered and then extracted by 2 liters of methanol by refluxing for $48 \mathrm{hr}$. The extract obtained was vacuum evaporated to give the crude extract which was redissolved with distilled water just before oral administration. Each extract was given in a dose equal 100 $\mathrm{mg} / \mathrm{kg}$ (Abdel-Zaher et al., 2005)

\section{Sampling and tissue extraction:}

At the end of the experimentation period, over night fasted rats were sacrificed using a sharp razor blade. Blood samples were collected in clean nonheparinized centrifuge tubes and only few droplets were placed in clean heparinized tubes for measuring hemoglobin, then the tubes were let to stand for $15 \mathrm{~min}$ at $30^{\circ} \mathrm{C}$ after which the non heparinized tubes were centrifuged at $3000 \mathrm{rpm}$ for $15 \mathrm{~min}$. Blood sera were carefully separated and each sample were labeled and kept at $-20^{\circ} \mathrm{C}$ for subsequent analysis. Thereafter, liver and pancreas specimens were quickly removed, 
weighed and then liver homogenized in cold distilled water to form $10 \%(\mathrm{w} / \mathrm{v})$ homogenate .Then they were kept at $-20^{\circ} \mathrm{C}$ for later different biochemical determination.

\section{Experiments}

The concentration of glucose in serum was estimated by the method Trinder (1969). Insulin was measured by the method of Flier et al. (1976). The concentration of hemoglobin in serum was estimated by the method of Van and Zijlstra (1961). The concentration of total lipids in serum was estimated by the method of Zollner and Kirsch (1962). The concentration of cholesterol in serum was estimated by the method of Meiattini (1978). The concentration of triglyceride in serum was estimated by the method of Buccolo (1973). The concentration of HDL and LDL in serum was estimated by the method of Grove (1979). The amount of Malondialdehyde (MDA) was measured by the method of Ohkawa et al. (1982). Protein carbonyl content was measured by method of Smith et al. (1961). SOD was assayed by the procedure of Nishikimi $\boldsymbol{e t}$ al. (1972). The method was adopted by Prins and Loose (1969). Catalase activity was determined by the method of Bock $\boldsymbol{e t}$ al. (1980). Glutathione-S-transferase (GST) activity was measured by the method of Habig et al. (1974). The concentration of total antioxidant capacity in serum was estimated by the method of Koracevic (2001). The concentration of total nitric oxide in serum was estimated by the method of Montgomery and Dymock (1961).

\section{Statistical analysis}

Statistical analysis was performed using MINITAB for Windows statistical package (Version 13) 2001. All results were calculated as the percentage of mean control values. Group results were then expressed as mean percentages \pm the standard error of the mean (S.E.M.). Statistical differences from control were determined using one way analysis of variance with a Dunnett correction for multiple comparisons.

\section{Results}

Streptozotocin caused disturbances in all the measured parameters represented as a significant increase in serum glucose levels (hyperglycemia), significant body weight loss, significant decreased $(\mathrm{p} \leq 0.05)$ insulin levels and significant increase in the lipid profile except HDL cholesterol which showed significant decrease. STZ also showed significant increased content of free radicals represented in significant increase in MDA and Protein carbonyl contents and this disturbance is accompanied with decreased antioxidants which were SOD, GSH, CAT, GST and serum TAOC with significant decrease in NO levels. Treatment with the crude extracts of Zizyphus spina-christi, Olea europaea or Morus alba alone or as a mixture treatment were ameliorated the previous parameters specially blood glucose levels. Zizyphus spina-christi was more effective for serum glucose level. The present data also showed that the administration of the crude extracts of each plant was much better than administrating them in combination. The 3 extracts decreased serum glucose levels, increased body weight, increased insulin and hemoglobin levels. They also ameliorated lipid profile and antioxidants contents in the liver and total antioxidant capacity in serum in addition; the extracts used in this experiment worked as free radical scavengers and this was confirmed by the reduction of MDA, PC contents. Unexpected result of NO levels in serum was obtained that the 3 plant extractions increased NO levels. 
Effects of the....

Table (1) Serum Glucose level, serum insulin level, blood hemoglobin level and \% of body wt gain in control and different treated animal groups.

\begin{tabular}{|c|c|c|c|c|c|c|c|c|c|c|}
\hline \multirow[t]{2}{*}{ Parameter } & \multicolumn{5}{|c|}{ Non diabetic groups } & \multicolumn{5}{|c|}{ Diabetic groups } \\
\hline & Control & ZSC & Olea & Morus & Mix & Diabetic & ZSC & Olea & Morus & Mix \\
\hline $\begin{array}{l}\text { Glucose } \\
(\mathrm{mg} / \mathrm{dl})\end{array}$ & $\begin{array}{l}82.0 \\
\pm \\
0.52\end{array}$ & $\begin{array}{l}81.3 \\
\pm \\
0.26\end{array}$ & $\begin{array}{l}83.3 \\
\pm \\
0.46\end{array}$ & $\begin{array}{l}80.9 \\
\pm \\
0.29\end{array}$ & $\begin{array}{l}83.6 \\
\pm \\
0.90\end{array}$ & $\begin{array}{l}384.8^{\mathrm{a}} \\
\pm \\
1.6\end{array}$ & $\begin{array}{l}152^{\mathrm{ab}} \\
\pm \\
1.38\end{array}$ & $\begin{array}{l}174.4^{\mathrm{ab}} \\
\pm \\
1.02\end{array}$ & $\begin{array}{l}175.6^{\mathrm{ab}} \\
\pm \\
1.00\end{array}$ & $\begin{array}{l}193.6^{\mathrm{ab}} \\
\pm \\
1.16\end{array}$ \\
\hline $\begin{array}{l}\text { Insulin } \\
(\mathrm{mg} / \mathrm{dl})\end{array}$ & $\begin{array}{l}3.8 \\
\pm \\
0.16\end{array}$ & $\begin{array}{l}3.9 \\
\pm \\
0.04\end{array}$ & $\begin{array}{l}3.8 \\
\pm \\
0.13\end{array}$ & $\begin{array}{l}3.9 \\
\pm \\
0.07\end{array}$ & $\begin{array}{l}3.8 \\
\pm \\
0.28\end{array}$ & $\begin{array}{l}2.2^{\mathrm{a}} \\
\pm \\
0.14\end{array}$ & $\begin{array}{l}3.4^{\mathrm{b}} \\
\pm \\
0.1\end{array}$ & $\begin{array}{l}3.3^{b} \\
\pm \\
0.2\end{array}$ & $\begin{array}{l}3.1^{b} \\
\pm \\
0.17\end{array}$ & $\begin{array}{l}2.8 \\
\pm \\
0.13\end{array}$ \\
\hline $\begin{array}{l}\text { Hemoglobin } \\
(\mathrm{g} / \mathrm{dl})\end{array}$ & $\begin{array}{l}13.7 \\
\pm \\
0.081\end{array}$ & $\begin{array}{l}13.8 \\
\pm \\
0.125\end{array}$ & $\begin{array}{l}13.7 \\
\pm \\
0.128\end{array}$ & $\begin{array}{l}14.2^{\mathrm{a}} \\
\pm \\
0.1\end{array}$ & $\begin{array}{l}13.7 \\
\pm \\
0.068\end{array}$ & $\begin{array}{l}11.22^{\mathrm{a}} \\
\pm \\
0.198\end{array}$ & $\begin{array}{l}13.5^{b} \\
\pm \\
0.157\end{array}$ & $\begin{array}{l}13.2^{b} \\
\pm \\
0.066\end{array}$ & $\begin{array}{l}13.3^{\mathrm{b}} \\
\pm \\
0.089\end{array}$ & $\begin{array}{l}13.2^{b} \\
\pm \\
0.169\end{array}$ \\
\hline $\begin{array}{l}\text { \% of Body } \\
\text { wt gain. }\end{array}$ & $\begin{array}{c}11.7 \\
\pm \\
0.3\end{array}$ & $\begin{array}{c}11.4 \\
\pm \\
0.04\end{array}$ & $\begin{array}{c}15.6^{\mathrm{a}} \\
\pm \\
0.02\end{array}$ & $\begin{array}{c}11 \\
\pm \\
0.1\end{array}$ & $\begin{array}{c}6.3^{\mathrm{a}} \\
\pm \\
0.06\end{array}$ & $\begin{array}{c}2^{\mathrm{a}} \\
\pm \\
0.07\end{array}$ & $\begin{array}{c}3.9^{\mathrm{ab}} \\
\pm \\
0.01\end{array}$ & $\begin{array}{c}4.9^{\mathrm{ab}} \\
\pm \\
0.06\end{array}$ & $\begin{array}{c}2.6^{\mathrm{ab}} \\
\pm \\
0.03\end{array}$ & $\begin{array}{c}2.4^{\mathrm{ab}} \\
\pm \\
0.02\end{array}$ \\
\hline
\end{tabular}

${ }^{\mathrm{a}}=$ significance $\leq .05$ as compared with untreated control.

$\mathrm{b}=$ significance $\leq .05$ as compared with diabetic control.

Table 2 lipid profile in control and different treated animal groups

\begin{tabular}{|c|c|c|c|c|c|c|c|c|c|c|}
\hline \multirow[t]{2}{*}{ Parameter } & \multicolumn{5}{|c|}{ Non diabetic groups } & \multicolumn{5}{|c|}{ Diabetic groups } \\
\hline & Control & ZSC & Olea & Morus & Mix & Diabetic & ZSC & Olea & Morus & Mix \\
\hline $\begin{array}{c}\text { Total lipids } \\
\text { (mg/dl) }\end{array}$ & $\begin{array}{c}220.2 \\
\pm \\
0.9\end{array}$ & $\begin{array}{c}226 \\
\pm \\
1.5\end{array}$ & $\begin{array}{c}219 \\
\pm \\
1.8\end{array}$ & $\begin{array}{c}224.4 \\
\pm \\
1.4\end{array}$ & $\begin{array}{c}228^{\mathrm{a}} \\
\pm \\
1.3\end{array}$ & $\begin{array}{c}997.5^{\mathrm{a}} \\
\pm \\
1.7\end{array}$ & $\begin{array}{c}454^{\mathrm{ab}} \\
\pm \\
1.8\end{array}$ & $\begin{array}{c}461^{\mathrm{ab}} \\
\pm \\
0.9\end{array}$ & $\begin{array}{c}495.5^{\mathrm{ab}} \\
\pm \\
1.9\end{array}$ & $\begin{array}{c}496^{\mathrm{ab}} \\
\pm \\
2\end{array}$ \\
\hline $\begin{array}{c}\text { Cholesterol } \\
\text { (mg/dl) }\end{array}$ & $\begin{array}{c}121.7 \\
\pm \\
0.9\end{array}$ & $\begin{array}{c}124.2 \\
\pm \\
1\end{array}$ & $\begin{array}{c}123.2 \\
\pm \\
1\end{array}$ & $\begin{array}{c}123.3 \\
\pm \\
0.8\end{array}$ & $\begin{array}{c}119.3 \\
\pm \\
0.9\end{array}$ & $\begin{array}{c}299.1^{\mathrm{a}} \\
\pm \\
1\end{array}$ & $\begin{array}{c}144.9^{\mathrm{ab}} \\
\pm \\
1.4\end{array}$ & $\begin{array}{c}148.9^{\mathrm{ab}} \\
\pm \\
0.7\end{array}$ & $\begin{array}{c}157.3^{\mathrm{ab}} \\
\pm \\
1.5\end{array}$ & $\begin{array}{c}157.9^{\mathrm{ab}} \\
\pm \\
1\end{array}$ \\
\hline $\begin{array}{c}\text { TG } \\
(\mathbf{m g} / \mathrm{dl})\end{array}$ & $\begin{array}{c}86.6 \\
\pm \\
0.8\end{array}$ & $\begin{array}{c}89.1 \\
\pm \\
0.7\end{array}$ & $\begin{array}{c}72^{\mathrm{a}} \\
\pm \\
0.9\end{array}$ & $\begin{array}{c}91.7 \\
\pm \\
1\end{array}$ & $\begin{array}{c}94 \\
\pm \\
1.5\end{array}$ & $\begin{array}{c}484.7^{\mathrm{a}} \\
\pm \\
2\end{array}$ & $\begin{array}{c}125.4^{\mathrm{ab}} \\
\pm \\
0.9\end{array}$ & $\begin{array}{c}173.9^{\mathrm{ab}} \\
\pm \\
0.5\end{array}$ & $\begin{array}{c}189.2^{\mathrm{ab}} \\
\pm \\
1.4\end{array}$ & $\begin{array}{c}329^{\mathrm{ab}} \\
\pm \\
0.7\end{array}$ \\
\hline $\begin{array}{c}\text { HDL } \\
(\mathrm{mg} / \mathrm{dl})\end{array}$ & $\begin{array}{c}56 \\
\pm \\
0.8\end{array}$ & $\begin{array}{c}60^{\mathrm{a}} \\
\pm \\
0.8\end{array}$ & $\begin{array}{c}67.2^{\mathrm{a}} \\
\pm \\
0.7\end{array}$ & $\begin{array}{c}59.1^{\mathrm{a}} \\
\pm \\
0.3\end{array}$ & $\begin{array}{c}54.7 \\
\pm \\
0.9\end{array}$ & $\begin{array}{c}35.5^{\mathrm{a}} \\
\pm \\
0.8\end{array}$ & $\begin{array}{c}42.5^{\mathrm{ab}} \\
\pm \\
0.8\end{array}$ & $\begin{array}{c}39.6^{\mathrm{ab}} \\
\pm \\
0.5\end{array}$ & $\begin{array}{c}42.3^{\mathrm{ab}} \\
\pm \\
1\end{array}$ & $\begin{array}{c}36.1^{\mathrm{ab}} \\
\pm \\
0.6\end{array}$ \\
\hline $\begin{array}{c}\text { LDL } \\
(\mathrm{mg} / \mathrm{dl})\end{array}$ & $\begin{array}{c}48.5 \\
\pm \\
0.8\end{array}$ & $\begin{array}{c}46.8 \\
\pm \\
0.8\end{array}$ & $\begin{array}{c}41.5^{\mathrm{a}} \\
\pm \\
0.5\end{array}$ & $\begin{array}{c}45.8 \\
\pm \\
0.4\end{array}$ & $\begin{array}{c}45.8 \\
\pm \\
0.9\end{array}$ & $\begin{array}{c}166.6^{\mathrm{a}} \\
\pm \\
1.6\end{array}$ & $\begin{array}{c}77.3^{\text {ab }} \\
\pm \\
0.9\end{array}$ & $\begin{array}{c}74.5^{\mathrm{ab}} \\
\pm \\
0.8\end{array}$ & $\begin{array}{c}77^{\text {ab }} \\
\pm \\
1\end{array}$ & $\begin{array}{c}56^{6} \\
\pm \\
1\end{array}$ \\
\hline
\end{tabular}

${ }^{\mathrm{a}}=$ significance $\leq .05$ as compared with untreated control.

${ }^{\mathrm{b}}=$ significance $\leq .05$ as compared with diabetic control. 
Table 3 hepatic MDA, PC and antioxidants in control and different treated animal groups

\begin{tabular}{|c|c|c|c|c|c|c|c|c|c|c|}
\hline \multirow[t]{2}{*}{ Parameter } & \multicolumn{5}{|c|}{ Non diabetic groups } & \multicolumn{5}{|c|}{ Diabetic groups } \\
\hline & control & ZSC & Olea & Morus & Mix & Diabetic & ZSC & Olea & Morus & Mix \\
\hline $\begin{array}{c}\text { MDA } \\
\text { nM/mg wt } \\
\text { tissue }\end{array}$ & $\begin{array}{c}96.9 \\
\pm \\
0.8\end{array}$ & $\begin{array}{c}96.2 \\
\pm \\
0.8\end{array}$ & $\begin{array}{c}96.6 \\
\pm \\
0.7\end{array}$ & $\begin{array}{c}95.6 \\
\pm \\
0.9\end{array}$ & $\begin{array}{c}96.8 \\
\pm \\
0.6\end{array}$ & $\begin{array}{c}202.6^{\mathrm{a}} \\
\pm \\
0.9\end{array}$ & $\begin{array}{c}195.4^{\mathrm{ab}} \\
\pm \\
0.7\end{array}$ & $\begin{array}{c}194^{\mathrm{ab}} \\
\pm \\
1.1\end{array}$ & $\begin{array}{c}199.1^{\mathrm{ab}} \\
\pm \\
0.5\end{array}$ & $\begin{array}{c}197^{\text {ab }} \\
\pm \\
0.9\end{array}$ \\
\hline $\begin{array}{c}\mathrm{PC} \\
\mathrm{nM} / \mathrm{mg} \text { wt } \\
\text { tissue }\end{array}$ & $\begin{array}{c}43.2 \\
\pm \\
1.24 \\
\end{array}$ & $\begin{array}{c}36.1^{\mathrm{a}} \\
\pm \\
1.06 \\
\end{array}$ & $\begin{array}{c}39.4^{\mathrm{a}} \\
\pm \\
0.39 \\
\end{array}$ & $\begin{array}{c}37^{\mathrm{a}} \\
\pm \\
1.73 \\
\end{array}$ & $\begin{array}{c}40.5^{\mathrm{a}} \\
\pm \\
0.6 \\
\end{array}$ & $\begin{array}{c}304.5 \mathrm{a} \\
\pm \\
4.94 \\
\end{array}$ & $\begin{array}{c}86.5^{\mathrm{ab}} \\
\pm \\
1.23 \\
\end{array}$ & $\begin{array}{c}90.6^{\mathrm{ab}} \\
\pm \\
0.48 \\
\end{array}$ & $\begin{array}{c}88.9^{\mathrm{ab}} \\
\pm \\
0.997 \\
\end{array}$ & $\begin{array}{c}105.5^{\text {ab }} \\
\pm \\
1.19\end{array}$ \\
\hline $\begin{array}{c}\text { SOD } \\
\text { U/g wt } \\
\text { tissue } \\
\end{array}$ & $\begin{array}{c}86.8 \\
\pm \\
1.7 \\
\end{array}$ & $\begin{array}{c}89.4^{\mathrm{a}} \\
\pm \\
0.5 \\
\end{array}$ & $\begin{array}{c}88.5 \\
\pm \\
1.5 \\
\end{array}$ & $\begin{array}{c}88.4 \\
\pm \\
0.9 \\
\end{array}$ & \begin{tabular}{c|}
86.9 \\
\pm \\
1.1 \\
\end{tabular} & $\begin{array}{c}69.4^{\mathrm{a}} \\
\pm \\
1.2 \\
\end{array}$ & $\begin{array}{c}74.0^{\mathrm{a}} \\
\pm \\
1.3 \\
\end{array}$ & $\begin{array}{c}73.9^{\mathrm{a}} \\
\pm \\
1 \\
\end{array}$ & $\begin{array}{c}77.6^{\mathrm{ab}} \\
\pm \\
1.3 \\
\end{array}$ & $\begin{array}{c}70.6^{\mathrm{a}} \\
\pm \\
0.7 \\
\end{array}$ \\
\hline $\begin{array}{c}\text { GSH } \\
\text { mg/g wt } \\
\text { tissue }\end{array}$ & $\begin{array}{c}4.1 \\
\pm \\
0.1\end{array}$ & $\begin{array}{c}4.6 \\
\pm \\
0.1\end{array}$ & $\begin{array}{c}4.2 \\
\pm \\
0.1\end{array}$ & $\begin{array}{c}4.8 \\
\pm \\
0.1\end{array}$ & $\begin{array}{c}4.2 \\
\pm \\
0.1\end{array}$ & $\begin{array}{c}2.7 \\
\pm \\
0.1\end{array}$ & $\begin{array}{c}3.5 \\
\pm \\
0.1\end{array}$ & $\begin{array}{c}3.3 \\
\pm \\
0.1\end{array}$ & $\begin{array}{c}3.6 \\
\pm \\
0.1\end{array}$ & $\begin{array}{c}3.3 \\
\pm \\
0.1\end{array}$ \\
\hline $\begin{array}{c}\text { CAT } \\
\mu M \\
\text { H2O2/Sec/g } \\
\text { wt tissue }\end{array}$ & $\begin{array}{c}1.6 \\
\pm \\
0.02\end{array}$ & $\begin{array}{c}2 \\
\pm \\
0.04\end{array}$ & $\begin{array}{c}2.1 \\
\pm \\
0.1\end{array}$ & $\begin{array}{c}2.9 \\
\pm \\
0.1\end{array}$ & $\begin{array}{c}2 \\
\pm \\
0.02\end{array}$ & $\begin{array}{c}0.7^{\mathrm{a}} \\
\pm \\
0.03\end{array}$ & $\begin{array}{c}1.6^{6} \\
\pm \\
0.02\end{array}$ & $\begin{array}{c}1.6^{6} \\
\pm \\
0.1\end{array}$ & $\begin{array}{c}1.7^{6} \\
\pm \\
0.1\end{array}$ & $\begin{array}{c}1.3 \\
\pm \\
0.03\end{array}$ \\
\hline $\begin{array}{c}\text { GST } \\
\mu \mathrm{M} / \mathrm{g} \text { wt } \\
\text { tissue }\end{array}$ & $\begin{array}{c}6.6 \\
\pm \\
0.126 \\
\end{array}$ & $\begin{array}{c}7.8^{\mathrm{a}} \\
\pm \\
0.08 \\
\end{array}$ & $\begin{array}{c}6.8 \\
\pm \\
0.12 \\
\end{array}$ & $\begin{array}{c}7.9^{\mathrm{a}} \\
\pm \\
0.2 \\
\end{array}$ & \begin{tabular}{c|}
$7.2^{\mathrm{a}}$ \\
\pm \\
0.1 \\
\end{tabular} & $\begin{array}{c}4.8^{\mathrm{a}} \\
\pm \\
0.3 \\
\end{array}$ & $\begin{array}{c}6.3^{\mathrm{b}} \\
\pm \\
0.2 \\
\end{array}$ & $\begin{array}{c}5.3^{\mathrm{a}} \\
\pm \\
0.4 \\
\end{array}$ & $\begin{array}{c}6.2^{\mathrm{b}} \\
\pm \\
0.06 \\
\end{array}$ & $\begin{array}{c}5.9 \\
\pm \\
0.4 \\
\end{array}$ \\
\hline $\begin{array}{l}\text { TAOC } \\
\mathrm{mM} / \mathrm{L}\end{array}$ & $\begin{array}{c}1.9 \\
\pm \\
0.04\end{array}$ & $\begin{array}{c}2.4^{\mathrm{a}} \\
\pm \\
0.06\end{array}$ & $\begin{array}{c}2.4^{\mathrm{a}} \\
\pm \\
0.05\end{array}$ & $\begin{array}{c}2.4^{\mathrm{a}} \\
\pm \\
0.06\end{array}$ & $\begin{array}{c}1.8 \\
\pm \\
0.05\end{array}$ & $\begin{array}{c}0.9^{\mathrm{a}} \\
\pm \\
0.06\end{array}$ & $\begin{array}{c}2.1^{\mathrm{b}} \\
\pm \\
0.04\end{array}$ & $\begin{array}{c}2^{\mathrm{b}} \\
\pm \\
0.03\end{array}$ & $\begin{array}{c}c^{2} 1^{\mathrm{b}} \\
\pm \\
0.1\end{array}$ & $\begin{array}{c}1.6^{b} \\
\pm \\
0.05\end{array}$ \\
\hline $\begin{array}{c}\mathrm{NO} \\
\mu \mathrm{mol} / \mathrm{L}\end{array}$ & $\begin{array}{c}50.4 \\
\pm \\
1.9\end{array}$ & $\begin{array}{c}53.5 \\
\pm \\
1.3\end{array}$ & $\begin{array}{c}50.4 \\
\pm \\
1.9\end{array}$ & $\begin{array}{c}52.4 \\
\pm \\
2\end{array}$ & $\begin{array}{c}53.5 \\
\pm \\
2.3 \\
\end{array}$ & $\begin{array}{c}21.5^{\mathrm{a}} \\
\pm \\
1.3\end{array}$ & $\begin{array}{c}49.9^{b} \\
\pm \\
1.5\end{array}$ & $\begin{array}{c}45.7^{b} \\
\pm \\
1.4\end{array}$ & $\begin{array}{c}48.7^{b} \\
\pm \\
2.2\end{array}$ & $\begin{array}{c}46.7^{\mathrm{b}} \\
\pm \\
1.8\end{array}$ \\
\hline
\end{tabular}

${ }^{\mathrm{a}}=$ significance $\leq .05$ as compared with untreated control.

$\mathrm{b}=$ significance $\leq .05$ as compared with diabetic control.

\section{Discussion}

In the present study the alcoholic crude extracts of Zizyphus spina-christi, Morus alba and Olea europaea leaves alone or as a mixture were used to identify their hypoglycemic and antioxidative effect as well as their effect on body weight, insulin, hemoglobin, lipid profile and oxidative stress markers. The oral administration of these extracts daily at a dose of $100 \mathrm{mg} / \mathrm{kg}$ for 5 weeks showed a significant amelioration in glucose levels and most of the measured parameters in normal and diabetic rats.

The present results showed that a single injection of STZ to rats of a dose $50 \mathrm{mg} / \mathrm{kg}$ body weight caused a significant increase in serum glucose levels and significant decrease in body weight, serum insulin and blood hemoglobin levels as compared to the control group. These results agreed with Ruzaidi et al. (2005) who reported that intraperitoneal administration of STZ led to five-fold elevation of serum 
fasting glucose levels. In addition in the present work STZ injected rats showed a significant increase in total lipids, cholesterols, triglycerides and low density lipoprotein (LDL) levels and a significant decrease in high density lipoprotein (HDL) levels. These findings are consistence with Hye et al. (2009) who stated that the levels of serum lipids are usually elevated in diabetes mellitus, and this represents the risk of coronary heart disease. The hyperglycemic effect of STZ showed significant increase in oxidative stress markers (lipid peroxidation and protein oxidation) and significant decrease in antioxidants status. Similar changes were already observed in different experimental situations reported by Rajani et al. (2008). These effects may take place due to STZ injection, which destroys the islet beta cells which associated with generation of free radicals and rise in the oxidative stress markers (Bhor et al., 2004). In the present work Zizyphus spina-christi extract showed the highest improvement of serum glucose levels in diabetic rats as compared to the control. The hypoglycemic effect of Zizyphus spina-christi was also observed by Glombitza et al. (1994) and AbdelZaher et al. (2005) who revealed that the alcoholic extract of Zizyphus spina-christi leaves improved glucose utilization in diabetic rats after 4 weeks of treatment because of the presence of major saponin glycoside (christinin-A).

In addition the present results showed the hypoglycemic effect of Olea europaea on diabetic rats. Gonzalez et al. (1992) indicated that Olea europaea possessed a hypoglycemic effect by two mechanisms the first is by potentiation of glucose induced insulin release and the second is by increasing peripheral uptake of glucose. Administration of Morus alba alcoholic crude extract also showed significant decrease in serum glucose levels as compared to diabetic control rats. Andallu and Varadacharyulu (2003) reported that mulberry administration remarkably decreased blood glucose concentrations in diabetic rats. This effect may be due to the presence of the $\mathrm{N}$ containing sugars which inhibit the functions of $\alpha$-glucosidase, $\alpha$-mannosidase and B-galactosidase (Asano et al., 1994) and fagomine which potentiates the glucose induced insulin release similar to the action of glibenclamide (Kimura et al., 1995) as well as increasing the tissue uptake of glucose (Chen et al., 1995). As the best of our knowledge there is no enough data supporting the effect of the administration of the mixture of the three extracts on serum glucose levels or other measured parameters. It is believed that the hypoglycemic effect of this mixture may be due to the presence of hypoglycemic constituents which are found in each of those plants.

STZ treated group showed a significant decrease in serum insulin levels. This result is in harmony with SubashBabu et al. (2009) who reported that STZ showed a significant decrease in serum insulin levels as compared with control rats. Jong-Dae et al. (2007) cleared that in STZ treated rats the numbers of immunoreactive insulin-producing cells were reduced and they were distributed in restricted pancreatic islets.

Treatment of diabetic rats with Zizyphus spina-christi, Olea europaea and Morus alba leaves crude extracts showed significant increase in serum insulin levels. Abdel-Zaher et al. (2005) reported that the saponin glycoside which is the active constituent in Zizyphus spina-christi leaves stimulate insulin secretion. In addition Gonzalez et al. (1992) stated that the hypoglycemic effect of olive leaves may be due to improved glucose stimulated insulin release. Singab et al. (2005) cleared that this effect may be attributed to the high flavonoids content of Morus alba leaves which increased antioxidant mechanisms and may be preserves the capability of insulin secretion.

In the present study the data showed significant body weight loss in diabetic rats when compared to the control group.

Jagannath and Surendra (2004) indicated that administration of STZ resulted in body weight loss. This may be due to protein sparing action i.e. gluconeogenesis from muscle protein (ketogenic amino acid) and 
this would result in decrease in total protein (Ene et al., 2007).

Goldstein et al. (2004) also referred that the metabolism of glucose, proteins and lipids is abnormal in diabetes due to insulin secretion defect, leading to various metabolic disorders and hence decrease body weight.

Treatment of diabetic rats with Zizyphus spina-christi, Olea europaea and Morus alba leaves crude extracts resulted in body weight gain as compared to the diabetic group. This may be due to the improvement of serum glucose levels. These results are compatible with AlAzzawie and Alhamdani (2006) for Olea europaea Jamshid and Prakash (2008) for Morus alba leaves. They indicated that the increase in body weight may be attributed to the improvement in serum glucose levels and metabolism.

Diabetic rats showed great disturbance in lipid profile as they had very high levels of total lipids, total cholesterol, triglycerides and low density lipoprotein (LDL) and very low levels of high density lipoprotein (HDL). These results are similar to those obtained by Zargar et al. (1995).

Treatment of diabetic rats with Zizyphus spina-christi, Olea europaea and Morus alba greatly normalized measured lipid profile as compared to the diabetic group. These results agreed with those of Hussein et al. (2006). This may be attributed to saponins in Zizyphus which has a hypolipidimic effects by decreasing total cholesterol, triglycerides, and LDL-C in hyperlipidimic rats (Zhang et al., 2004; Zhao et al., 2005). Khan et al. (2007) reported that Olea europaea leaf showed hypolipidimic activity when studied in laboratory animals. This effect may be due to the presence of the active constituent oleuropein, with a proposed mechanism of action of potentiation of glucose-induced insulin release, and an increase in peripheral blood glucose uptake. In addition El-Beshbishy et al. (2006) reported the same effect of Morus alba on cholesterol, T.G, LDL-c and HDL-c. This was due to the presence of flavonoids in Morus alba leaves. On the other hand Weggemans and Trautwein (2003) revealed that flavonoids intake decreased LDL-C and increased HDL-C that may hasten removal of cholesterol from peripheral tissue to liver for catabolism and excretion.

The present results showed the antioxidative effect of Zizyphus spina christi, Olea europaea and Morus alba leaves extract by decreasing the hepatic MDA and protein carbonyl (PC) contents. These results were in accordance with the previous studies of Hussein et al. (2006) for Zizyphus spina christi. This may be attributed to the presence of tannins (Adzu et al., 2001) and carotenes (Guil-Guerrero et al., 2004) in some Zizyphus species.

$$
\text { Al-Azzawie and Alhamdani }
$$

(2006) reported that oleuropein the active constituent of Olea europaea leaves have the ability to scavenger the superoxide anions. Andallu and Varadacharyulu (2003) reported that Morus alba leaves extract treatment attenuated MDA levels. This may be due to the antioxidative effect of nine flavonoids (Husain et al., 1984) and moracins (Sharma et al., 2001) present in the leaves which act as strong superoxide radical scavengers and singlet oxygen quenchers.

Present data showed that Zizyphus spina christi, Olea europaea and Morus alba leaves extract ameliorated hepatic SOD activity in different treated diabetic groups as compared to diabetic control group. The administration of Zizyphus was able to increase the activities of endogenous antioxidant enzymes such as SOD because it has a maximum conjugation with injurious free radicals and diminishes their toxic properties

(Shen et al., 2009). In addition Somova et al. (2003) reported that leaves of Olea europaea increased SOD activity and claimed that this effect was due to the presence of oleanolic and ursolic acid which act as antioxidant substances. Also, Andallu and Varadacharyulu (2003) reported that the antioxidant effect of Morus alba is due to the presence of antioxidant flavonoids (quercetins) and moracins in leaves. In the present study all treated diabetic groups showed significant increase in hepatic Glutathione content as compared to the diabetic group. 
Dembinska-Kiec et al. (2008) reported that Zizyphus as well as Trigonella foenumgraceum $L$. have antioxidant effect for STZ diabetic rats. This may be attributed to the presence of flavonoids which have an antioxidant activity. Al-Azzawie and Alhamdani (2006) reported that the glutathione level was ameliorated in diabetic rabbits when treated with oleuropein (the active constituent of Olea europaea). The observed enhancement in GSH content could be attributed to the sparing effect of oleuropein in competing with free radicals that burden the antioxidative function of these antioxidants. The experimental control group and diabetic group that received Morus alba crude extract showed significant increase in hepatic GSH content as compared with control group and diabetic group. These results are similar to those obtained by Andallu and Varadacharyulu (2003) who reported that mulberry improved the concentrations of glutathione due to the presence of antioxidant flavonoids and moracins in leaves. Catalase activity was greatly improved in all diabetic rats treated with herbal extracts. Shen et al. (2009) cleared that administration of Zizyphus improved hepatic catalase levels. They commented that Zizyphus provides maximum conjugation with injurious free radicals and diminishes their toxic properties.

Current data which representing the ameliorating effect of Morus alba leaves on catalase activity disagreed with Andallu and Varadacharyulu (2003) who demonstrated that Morus alba decreased catalase activity while we agree with AlAzzawie and Alhamdani (2006) who reported that catalase activity is decreased in diabetic rabbits and increased by the treatment with Olea europaea active constituent. Glutathione S-transferase activity was increased in diabetic rats received the methanolic crude extract of Zizyphus spina christi leaves and this improvement may be due to the presence of saponins glucosides and flavonoids which act as antioxidants (Agata et $\boldsymbol{a l}$., 2009).

Administration of Olea europaea leaves crude extract to diabetic rats did not affect GST activity as compared with the diabetic group. On the other hand administration of Morus alba leaves crude extract showed significant increase in hepatic GST content. On the contrary ElBeshbishy et al. (2006) reported that flavonoids showed no significant effect on the activity of plasma and liver GST. Andallu and Varadacharyulu, (2003) stated that GST activity was partially restored in diabetic group treated with mulberry leaves. This improvement might be due to the presence of antioxidant flavonoids and moracins in leaves. In addition Cai and Wei (1996) suggested that dietary intake of a flavonoids the active compounds in Morus alba leaves, enhanced the increase in GST activity.

Diabetic rats showed significant decrease in serum total antioxidant capacity as compared with the control group. This result in agreement with Jonathan et $\boldsymbol{a l}$. (2001) who commented that total antioxidant capacity was significantly lowered in the diabetic subjects than in the control subjects.

There is no available data showing the effect of Zizyphus spina christi on serum total antioxidant capacity. However many researches showed that Zizyphus spina christi is a strong antioxidant agent. Such researches explained that effect as a result of the presence of saponins glucosides and flavonoids which are strong antioxidants (Agata et al., 2009).

The present data showed increased total antioxidant capacity of Olea europaea methanolic extract treated rats (table 16). Ferreira et al. (2007) reported that Olea europaea leaves extract showed higher phenolic content. Pennycooke et al. (2005) reported that the antioxidant capacity was related to the content of phenolic compounds in their samples. Higher content of total phenolics reflected higher total antioxidant capacity values. Also Skerget et al. (2005) had reported that the antioxidant activity of plant materials is well correlated with the content of their phenolic compounds. For Morus alba extract Arabshahi-Delouee and Urooj (2007) reported that methanol proved to be the most efficient solvent for extraction of 
antioxidants from mulberry leaves as it contained the highest amount of phenolic compounds and also exhibited the strongest antioxidant capacity as shown in table 16 .

The current data showed that nitric oxide (NO) levels reduced in diabetic rats as compared with control animals. The admenstration of various herbal extracts resulted in significant increase in NO levels as compared with diabetic rats. These results agreed with Awad et al. (2004) who indicated that the renal NO levels decreases in diabetic rats.

On the contrary the present results disagree with those obtained by Chien et al. (2005) as well as Vadde and Rama (2008) who reported that diabetic subjects had higher levels of NO as compared with the control group. They concluded that increased oxidative stress and changes in nitric oxide (NO) formation or activity play a major role in the complications of diabetes with decreased antioxidants. Also, Choi and Hwang (2005) revealed that methanolic extract of Morus alba leaves inhibited NO production.

\section{In conclusion:}

The present study demonstrates that the usage of the crude extracts of Zizyphus spina-christi, Olea europaea or Morus alba leaves individually as well as in combination daily at a dose of $100 \mathrm{mg} / \mathrm{kg}$ greatly ameliorates the diabetic disorders induced by streptozotocin in rats. Zizyphus spina-christi produces the highest hypoglycemic effect.

\section{References:}

Abdel-Zaher AO, Salim SY, Assaf MH, Abdel-Hady RH (2005): Antidiabetic activity and toxicity of Zizyphus spina-christi leaves. Journal of Ethnopharmacology; 101(1): 129-138 Adzu B, Amos S, wambebe C, and Gamaniel K (2001): Antinociceptive activity of Zizyphus spina-christi root bark extract. Fitoterapia; 72(4): 344-350

Agata Maria Pawlowska, Fabiano Camangi, Ammar Bader and Alessandra Braca (2009): Flavonoids of Zizyphus jujuba L. and Zizyphus spina-christi $(L$.) fruits. Food Chemistry; 112(4): 858-862

Al-Azzawie HF and Alhamdani MS (2006): Hypoglycemic and antioxidant effect of oleuropein in alloxan-induced diabetic rabbits. Life Sci.; 78(12): 1371-1377

Andallu B and Varadacharyulu NC (2003): Antioxidant role of mulberry (Morus indica L. cv. Anantha) leaves in streptozotocin-diabetic rats. Clinica Chimica Acta .,338(1-2): 3-10

Arabshahi-Delouee Saeedeh and Urooj Asna (2006): Antioxidant properties of various solvent extracts of mulberry (Morus indica L.) leaves. Food Chemistry; 102(4): 1233-1240

Asano N, Oseki K, Kizu $H$ and Matsui $K$ (1994): Nitrogen in the ring pyranoses and furanoses: structural basis of inhibition of mammalian glycosidases. J Med Chem; 37(22): 3701-3706.

Awad Alaa S, Webb Randy L, Carey Robert M and Siragy Helmy M (2004): Renal nitric oxide production is decreased in diabetic rats and improved by AT1 receptor blockade. Journal of hypertension; 22(8): 1571-1577

Bhor VM, Raghuram $\mathbf{N}$ and Sivakami $\mathbf{S}$ (2004): Oxidative damage and altered antioxidant enzyme activities in the small intestine of streptozotocin-induced diabetic rats. Int J Biochem Cell Biol; 36(1): 89-97

Bock P, Kramais R and Pavelka M (1980): Peroxisomes and Relatel Particles in Animal Tissues. Cell biology monographs; 7: 58-59

Buccolo G (1973): Quantitive determination of serum triglycerides by use of enzymes. Clin Chem; 19 (5): 476-482

Cai Q and Wei H (1996): Effect of dietary genistin on antioxidant enzyme activities in SENCAR mice. Nutrition and Cancer 25(1): 1-7 Ceriello A and Motz E (2004): Is oxidative stress the pathogenic mechanism underlying insulin resistance, diabetes, and cardiovascular disease? The common soil hypothesis revisited. Arterioscler Thromb. Vasc Biol; 24(5): 816-823

Chen F, Nakashima N, Kimura I and Kimura M (1995): Hypoglycemic activity and mechanisms of extracts from mulberry leaves (Folium mori) and cortex radicis in streptozotocin-induced diabetic mice. Yakugaku Zasshi; 115(6): 476-482

Chien WY, Yang KD, Eng HL, Hu YH, Lee PY, Wang ST and Wang PW (2005): Increased plasma concentration of nitric oxide in type 2 diabetes but not in nondiabetic individuals with insulin resistance. Diabetes \& Metabolism; 31(1): 63-68

Choi KM and Hwang JK (2005): Effects of Morus alba leaf extract on the production of nitric oxide prostaglandin E2 and cytokines in RAW2647 
macrophages. Fitoterapia; 76(7-8): 608613

Dembinska-Kiec Aldona, Mykkänen Otto, Kiec-Wilk Beata and Mykka"nen Hannu (2008): Antioxidant phytochemicals against type 2 diabetes. British Journal of Nutrition; 99 (E-Suppl1): ES109-117

El-Beshbishy HA, Singab AB, Sinkkonen S and Pihlaja Kalevi (2006): Hypolipidemic and antioxidant effects of Morus alba L. (Egyptian mulberry) root bark fractions supplementation in cholesterol-fed rats. Life Sciences; 78(23): 2724-2733

Ene AC, Nwankwo EA and Samdi LM (2007): Alloxan-induced diabetes in rats and the effects of black caraway (Carum carvi l.) oil on their body weight. Research journal of medicine and medical sciences, 2(2): 48-52

Fajans SS, Cloutier MC and Crowther RL (1997): Clinical and etiological heterogeneity of idiopathic diabetes mellitus (Banting Memoral lecture). Schweiz Med Wochenschr ,109(46): 1774-1785

Ferreira Isabel CFR, Lillian Barros, Maria Elisa Soares, Maria Lourdes Bastos and Jose Alberto Pereira (2007): Antioxidant activity and phenolic contents of Olea europaea L. leaves sprayed with different copper formulations. Food Chemistry 103(1): 188-195

Flier JS, Kahn CR, Jarrett DB and Roth J (1976): Characterization of antibodies to the insulin receptor-a cause of insulin-resistant diabetes in man. J Clin Invest; 58(6): 1442-1449 Gilberta Giacchetti, Leonardo A Sechi, Silvia Rilli and Robert M Carey (2005): The reninangiotensin-aldosterone system, glucose metabolism and diabetes. Endocrinology and Metabolism; 16(3): 120-126

Glombitza KW, Mahran GH, Mirhom YW, Ichel KG and Motawi TK, (1994): Hypoglycemic and antihyperglycemic effects of Zizyphus spina-christi in rats. Planta Medica; 60(3): 244-247

Goldstein DE, Little RR, Lorenz RA, Malone JI, Nathan D, Peterson CM and Sacks DB (2004): Test of glycemia in diabetes. Diabetes Care 27(7): 1761-1773

Gonzalez M, Zarzuelo A, Gamez MJ, Utrilla MP and Jimenez J, Osuna I (1992): Hypoglycemic activity of olive leaf. Planta Medica 58(6): 513-515

Grove TH (1979): Effect of reagent $\mathrm{pH}$ on Determination of HDL Cholesterol by precipitation with Sodium Phosphotungstatemagnesium. Clin Chem; 25: 560

Guil-Guerrero JL, Diaz Delgado A, Gonzalez MC and Torija Isasa ME, (2004): Fatty acids and cartotenes in some ber (Zizyphus jujuba
Mill) varieties. Plant Foods Hum Nutr; 59(1): 23-27

Habig H, Pabst J and Jakoby B (1974): Glutathione-S-Transferase the first enzyme step in mercapturic acid formation. J. Boil. Chem; 1(24): 7150-7139

Husain SR, Cillard J and Cillard P (1984): Hydroxyl radical scavenging activity of flavonoids. Phytochemistry; 26(9): 2489-2491

Hussein HM, El-Sayed EM and Aataa S (2006): Antihyperglycemic Antihyperlipidimic and Antioxidant effects of Zizyphus spina christi and Zizyphus jujuba in Alloxan diabetic rats. International journal of pharmacology; 2(5): 563-570

Hye Kyung KIM, Mi Jeong KIM, Eun Soon LYU, and Dong-Hoon SHIN (2009): Improvement of Diabetic Complication by Hydrangea Dulcis Folium in StreptozotocinInduced Diabetic Rats. Biol. Pharm. Bull. 32(1): 153-156

Jagannath G Satav and Surendra S Katyare (2004): Effect Of Streptozotocin-Induced Diabetes On Oxidative Energy Metabolism In Rat Liver Mitochondria - A Comparative Study Of Early And Late Effects. Indian Journal of Clinical Biochemistry; 19 (2): 23-31

Jamshid Mohammadi and Prakash R Naik (2008): Evaluation of hypoglycemic effect of Morus alba in an animal model. Indian journal of pharmacology; 40(1): 15-18

Jonathan Valabhji, Avril J Mccoll, William Richmond, Michael Schachter and Robert S Elkeles (2001): Total Antioxidant Status and Coronary Artery Calcification in Type 1 Diabetes. Diabetes care; 249(9): 1608-1613

Jong-Dae Kim, Seock-Man Kang, Mee-Yeon Park, Tae-Young Jung, Hae-Yun Choi, and Sae-Kwang Ku (2007): Ameliorative antidiabetic activity of Dangnyosoko, a Chinese herbal medicine, in diabetic rats. Bioscience, biotechnology and biochemistry; 71 (6): 1527 1534

Khan M Yaseen, Siddharth Panchal, Niraj Vyas, Amee Butani and Vimal Kumar (2007): Olea europaea: A Phyto-Pharmacological Review. Pharmacognosy Reviews; 1(1): 114118

Kimura M, Chen FJ, Nakashima N, Kimura I, Asano N and Koya SJ (1995):_Antihyperglycemic effects of $\mathrm{N}$-containing sugars derived from mulberry leaves in streptozotocininduced diabetic mice. Tradit Med; 12: 214 219

Koracevic D, Koracevic G, Djordjevic V, Andrejevic S and Cosic V (2001): Method for the measurement of antioxidant activity in human fluids. J Clin Pathol; 54(5): 356-361 
Meiattini F (1978): The 4-hydroxybenzoate/4aminophenazone Chromogenic System. Clin Chem; 24 (12): 2161-2165

Montgomery C and Dymock F (1961): The determination of nitrite in water. Analyst; 86: 414-416

Nishikimi M, Rao A and Yog K (1972): Colormetric determination of superoxide dismutase activity. Bioch Biophys. Res. Commun; 46: 849-851

Pennycooke Joyce C, Sam Cox and Cecil Stushnoff (2005): Relationship of cold acclimation, total phenolic content and antioxidant capacity with chilling tolerance in petunia (Petunia hybrida). Environmental and Experimental Botany 53(2): 225-232

Prins K and Loose A (1969): Glutathione chapter Biochemical Methods in Red cell Genetics. Edited Ac Press; N.Y.D London, 126-129

Ohkawa H, Wakatsuki A and Kaneada C (1982): Assay for lipid peroxides in animal tissue by thiobarbituric acid reaction. Anal Biochem; 95(2): 351-358

Rai MK (1995): A review on some antidiabetic plants of India. Ancient Sci Life; 14(3): 42-54

Rajani Kanth, Uma Maheswara Reddy and Raju TN (2008): Attenuation of streptozotocin-induced oxidative stress in hepatic and intestinal tissues of wistar rat by methanolic-garlic extract. Acta Diabetol 45(4): 243-251

Ruzaidi A, Amin I, Nawalyah AG, Hamid M and Faizul HA (2005): The effect of Malaysian cocoa extract on glucose levels and lipid profiles in diabetic rats. Journal of Ethnopharmacology 98(1-2): 55-60

Sharma R, Sharma A, Shono T, Takasugi M, Shirata A and Fugimura T (2001): Mulberry moracins: scavengers of UV stress-generated free radicals. Biosci Biotechnol Biochem; 65(6): 1402- 1405

Shen Xiangchun, Yuping, Tang Ruihui Yang, Li Yu, Fang Taihui and Duan Jin-ao (2009): The protective effect of Zizyphus jujube fruit on carbon tetrachloride-induced hepatic injury in mice by anti-oxidative activities. Journal of Ethnopharmacology; 122(3): 555-560

Singab AB, El-Beshbishy HA, Makiko Yonekawa, Taro Nomurac and Toshio Fukai (2005): Hypoglycemic effect of Egyptian Morus alba root bark extract: Effect on diabetes and lipid peroxidation of streptozotocin-induced diabetic rats. Journal of Ethnopharmacology; 100(3): 333-338

Skerget M, Kotnik P, Hadolin M, Hras AR, Simonic $\mathbf{M}$ and Knez $\mathbf{Z}$ (2005): Phenols, proanthocyanidins, flavones and flavonols in some plant materials and their antioxidant activities. Food Chemistry; 89(2): 191-198

Smith D, Carney M, Starke-Reed E, Oliver $\mathbf{N}$, Stadtman R, Floyd A and Markesbery $\mathbf{R}$ (1991): Excess brain protein oxidation and enzyme dysfunction in normal aging and Alzheimer disease. Proc.Nahacad. Sci; 88 (23): 105540-105543

Somova LI, Shode FO, Ramnanan $\mathbf{P}$ and Nadar A (2003): Antihypertensive, antiatherosclerotic and antioxidant activity of triterpenoids isolated from Olea europaea, subspecies Africana leaves. Journal of Ethnopharmacology; 84(2-3): 299-305

Subash-Babu P, Ignacimuthu S, Agastian B and Babu Varghese (2009): Partial keneration of b-cells in the islets of dingerhans by Nymphayol a sterol isolated from Nymphaea stellata (Willd.) flowers. Bioorganic \& Medicinal Chemistry 17(7): 2864-2870

Trinder P (1969): A colorimetric method for determination of glucose. Ann. Clin. Biochem; 6: $24-26$

Vadde Ramakrishna and Rama Jailkhani (2008): Oxidative stress in non-insulindependent diabetes mellitus (NIDDM) patients. Acta Diabetol; 45(1): 41-46

Van Kampen EJ and Zijlstra WG (1961): Standardization of hemoglobinometry. Clin. Chim; 6: 538-544

Weggemans RM and Trautwein EA (2003): Relation between soy-associated isoflavones and LDL and HDL cholesterol concentrations in humans: a Meta analysis. European Journal of Clinical Nutrition; 57(8): 940-946

Zargar Abdul Hamid, Wandroo Farooq A, Wadhwa Mool, Laway Bashir, Masoodi Shariq R and Shah Nissar A (1995): Serum Lipid Profile in Non-insulin-dependent Diabetes Mellitus Associated with Obesity. Int. J. Diab. Dev. Countries; 15: 9-13

Zhang XM, Qu SC, Sui DY, Yu XF and Lv ZZ (2004): Effects of ginsenoside-Rb on blood lipid metabolism and anti-oxidation in hyperlipidemia rats. Zhonyguo Zhong Yao Za Zhi 29(11): 1085-1088

Zhao L, Sim S, Shim H and Ha W (2005): Antiobese hypolipidimic effects of platycodin saponins IN diet induced obese rats: Evidence for lipase inhibition and calorie intake restriction. Int J. Obese; 29: 983-990

Zollner N and Kirsch k (1962): Microdetermination of lipids by the sulphophosphovanillin reaction. Z.Ges. Exp. Med; 135: 545-56. 
Effects of the....

تأثير المستخلصات الكحولية لأوراق نباتات السدر, الزيتون الإفريقي والتوت المصري علي

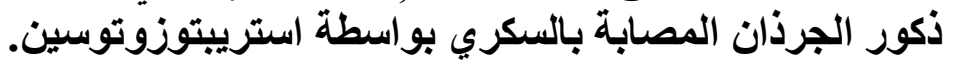

عزه إسماعيل عثمان*, ماهر عامر علي*, مددوح عبد المجيب**, روفان فاروق سماحة* قسم علم الحبوان*** قسم الكيمياء, كلية العلوم, جامعة المنصورة

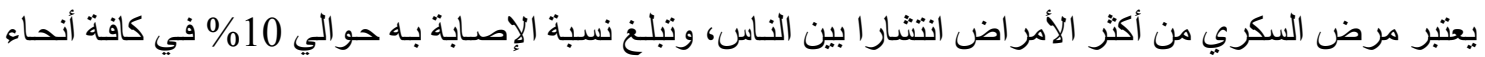

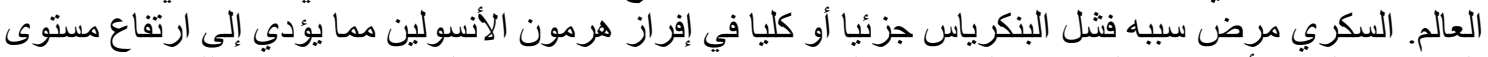

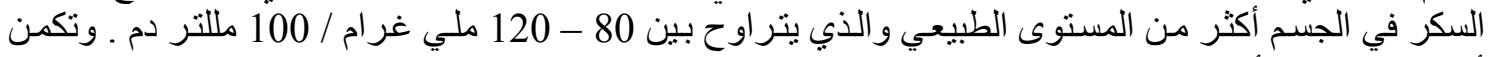

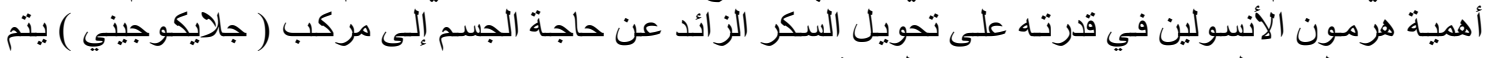

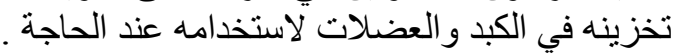

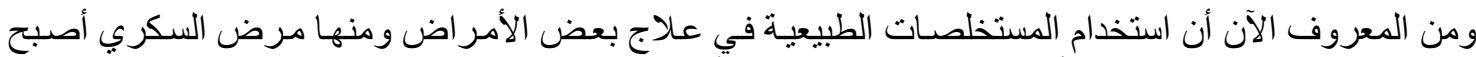

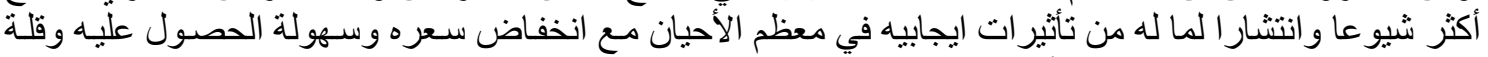

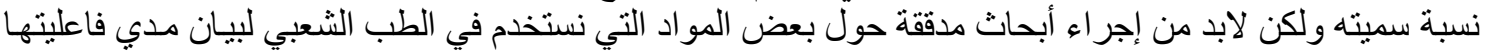

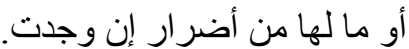

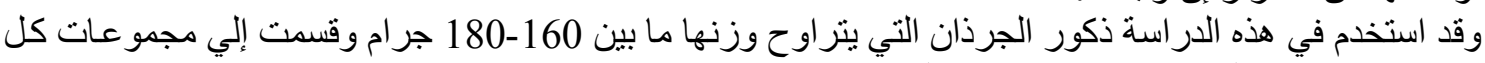
مجمو عه تحتوي علي 8 جرذان و هي كما يلي:-

\section{المجموعات الضابطة وتحتوي على عدة مجموعات وهى :-}

المجموعـة ( أ ) حيو انـات ضـابطة حقتـ بجر عـة واحدة مـن المـادة المذيبـة (Citrate buffer) في التجويف البريتوني.

المجموعة (ب) مجمو عه ضابطة حقتت بالمستخلص النباتي الخام لأوراق نبات السدر (النبق) بجرعة 100مجم/ كجم عن طريق الفم.

المجموعـة (جـ) مجمو عــه ضـابطة حقنـت بالمسـتخلص النبـاتي الخـام لأوراق نبـات الزيتـون الإفريقـي بجر عــة

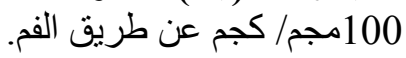

المجموعة ( د ) مجمو عه ضابطة حقتت بالمستخلص النباتي الخام لأوراق نبات التوت المصري بجرعة 100مجم/ كجم عن طريق الفم.

المجموعة (هـ) مجمو عه ضابطة حقتت بخليط من الثلاث مستخلصات معا بنسب منسـاوية بجر عة 100مجم/ كجم عن طريق الفم.

مجموعات الجرذان المستحثة كيميائيا بواسطة 50مجم/كجم من وزن الجسم استريبتوزوتوسين لإحداث مرض

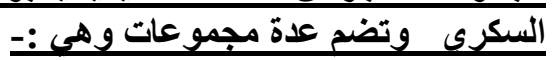

المجموعة ( أ ) حيو انات مصابة بمرض السكري لم يتم معالجتها.

المجموعة (ب) حيو انـات مصـابة بالسكري حقتت بالمستخلص النباتي الخام لأوراق نبات السدر (النبق) بجر عـة 100مجم/كجم عن طريق الفم.

المجموعـة (جـ) ) حيو انـات مصـابة بالسكري حقنت بالمستخلص النبـاتي الخـام لأور اق نبـات الزيتون الإفريقي بجر عة 100مجم/كجم عن طريق الفم. 
المجموعة ( د ) ) حيو انات مصابة بالسكري حقنت بالمستخلص النباتي الخام لأوراق نبات التوت المصري بجر عة 100مجم/كجم عن طريق الفم. (دمبر

المجموعة (هـ) ) حيو انـات مصسابة بالسكري حقتت بخليط من الثناث مستخلصسات معـا بنسب متسـاوية بجر عـة

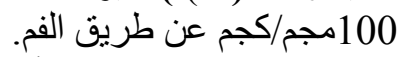

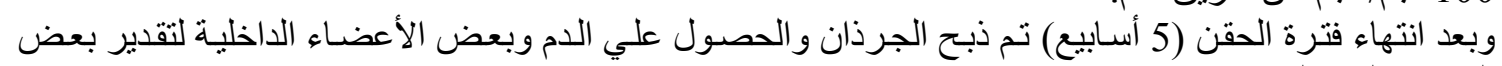
المعايير الفسيولوجية.

\section{ويمكن تلخيص النتائج كما يلي:-}

الاستربتوزوتوسين تسبب في حدوث خلل و اضح في كل القياسات ويتضح هذا الخلل في زيادة ملحوظة في مستوي

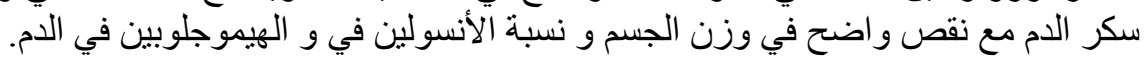

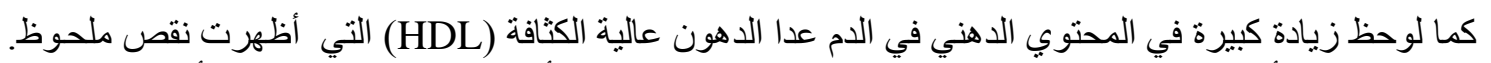

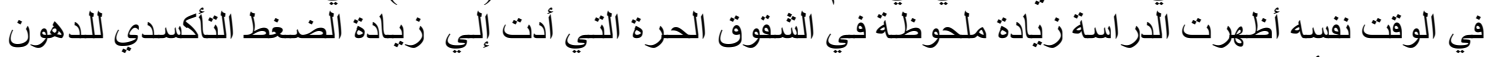

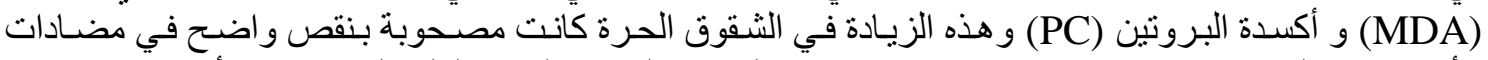

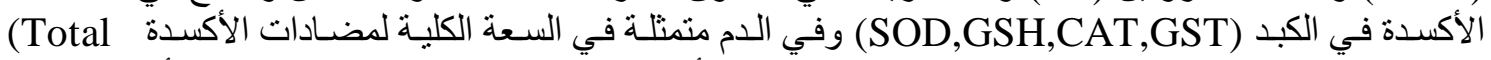

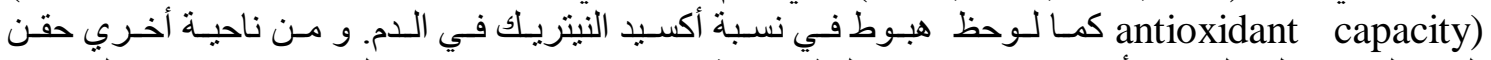

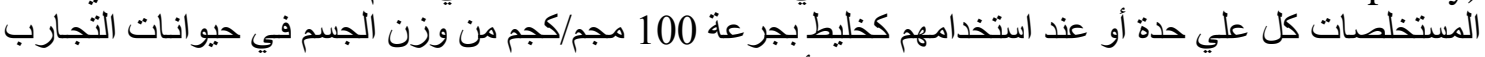

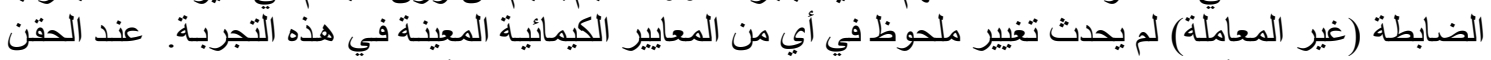

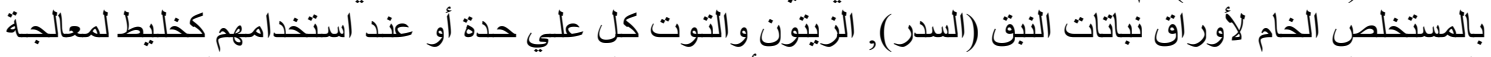

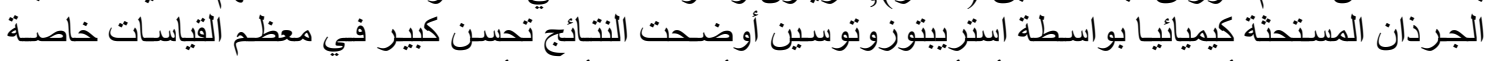
مستوي سكر الدم وأوضحت الدراسة أن أوراق نبات النبق أظهرت التأثير الأكبر في تخفيض نسبة النئ السكر في الدم. 